\title{
Perceptions of Canadian Provosts on the Institutional Role of Academic Libraries
}

\section{Mark Robertson}

\begin{abstract}
This study examines perceptions of provosts from Canadian researchintensive universities regarding their institution's academic libraries. Interviews conducted with nine provosts explored how they perceive academic libraries in terms of alignment with institutional mission, how they envision the future of their libraries, and what they interpret as indicators of success. The results suggest that provosts perceive libraries making significant contributions to research and student learning, particularly through the provision of access to information and the evolving role of library as place respectively. Other areas of library expertise, such as scholarly communication, appear somewhat less familiar to provosts, suggesting the need for library leaders to promote new roles within the institutional context.
\end{abstract}

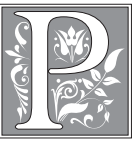

rovosts or academic vice-presidents are crucial stakeholders of academic libraries. At most institutions, libraries report directly to the provost, and the provost's support is essential for ongoing investment. Universities and research libraries are both in periods of rapid change. Fundamental questions are being asked of each, and traditional roles are being reassessed. In this context, it is important that the library community engage in discussions about the future of academic libraries with an awareness of how changes in the information environment interact with fundamental changes in the academy. Provosts' perspectives on these issues are particularly important. As senior administrators who are expected to play the role of chief academic visionary, provosts have a high-level perspective on the strategic directions of the institution and are responsible for guiding the academic mission. Few studies of provosts' perspectives on academic libraries have been carried out. The intent of this research is to investigate how provosts (or equivalent academic administrators) at Canadian research-intensive universities perceive the role of academic libraries in the context of their evolving institutions.

Interviews conducted with nine provosts explored how these leaders perceive academic libraries in terms of alignment with institutional mission, how they envision the future of their libraries, and what they interpret to be indicators of libraries' success. This report describes the framing of the project, the methodology, the results, and a discussion of implications. The findings provide insight into how academic research libraries are perceived by senior administrators to be evolving in the context of their institutions.

Mark Robertson is Associate University Librarian, Information Services in Scott Library at York University; e-mail: markr@yorku.ca. (C) 2015 Mark Robertson, Attribution-NonCommercial (http://creativecommons. org/licenses/by-nc/3.0/) CC BY-NC 


\section{Institutional Alignment and Library Futures}

Libraries exist within the context of larger systems, and it is their host systems that provide the rationale for their existence and from which libraries derive their ultimate mission. Eleanor Jo Rodger writes,

Those who care about thriving libraries must understand the library's host system. Why does it exist? What is its mission? Its history? What does it mean to be good or effective within that system?... Understanding our host systems is essential if we are to be vital components of their whole. ${ }^{1}$

It is primarily in relation to the mission of the university or college that academic libraries derive their value. "We are in trouble," Rodger writes, "if we stop doing those things that are understood to be part of our legitimizing story." ${ }^{2}$ The task of academic libraries then is to continually revisit the relationship to their institutions and track the ways in which they can contribute to the larger institutional mission. It is particularly crucial to revisit this relationship at this time of rapid change in higher education, libraries and in the profession of librarianship. Libraries must ensure they co-evolve with their institutions.

The perspectives of provosts provide a window into the ways in which academic libraries contribute to their communities in that provosts are generally responsible for guiding the academic mission of their institutions. The title "Provost" is used in the context of North American universities to refer to the person who is second in command at an institution after the university president and is in practice the key leader in regard to academic matters. Often the title is coupled with "Vice President Academic," though these roles are not synonymous. Maghroori and Powers argue that the role of the vice president academic is "to promote and maintain a distinctive academic vision," while the provost traditionally minds the administrative operations of the institution. ${ }^{3}$ Frequently, though, the distinction is blurred, especially since the roles are often held by the same individual. In the United States, the term "Chief Academic Officer" (CAO) is also used synonymously with the term "Provost." In Canadian research universities, a title such as "Provost and Vice-President Academic" is commonly used with the exception of Quebecois institutions where administrative structures are distinct. In Quebec, there is no simple equivalent to the position of provost; the nearest equivalent would be "Vice-rectorat." For the purposes of this report, the term "provost" will be used to represent the university's key academic leader who is generally second in command after the president.

Typically, academic libraries report to the provost. Paul Courant, Dean of Libraries and former Provost at University of Michigan writes:

The provost must ensure that the library is delivering value for the institution in which the library sits, and must continually assert the primacy of scholarship and academic work, including teaching, in the library's mission. Thus the provost identifies the library's objectives in the context of all the university's missions. ${ }^{4}$

The current research explores how provosts at Canadian research-intensive universities perceive academic libraries in the context of their institutions. Three lenses will be used to explore provosts' perceptions through interviews. First, how do provosts see their libraries contributing to the mission of their university? Second, how do provosts see their libraries evolving over the next 5-10 years, specifically in terms of the libraries' main functional areas: collections, expertise, and library as place? And third, what do they see as indicators of success of their libraries? What tells them that their libraries 
are vital, healthy, and successful organizations? In all these cases, the focus is on how the provosts perceive the academic libraries at their own institutions, as opposed to academic libraries in the abstract.

\section{Literature Review}

Studies of the views of provosts or other senior administrators regarding academic libraries are surprisingly few and far between. One of the earliest articles on the topic in the library and information science literature, "The Bottomless Pit, or the Academic Library as Viewed from the Administration Building," was published by Robert F. Munn in $1968 . .^{5}$ Munn, a librarian by profession, was at the time serving as acting provost at West Virginia University. He describes how the academic library was perceived by senior university administrators, especially in the context of broader institutional priorities and resource allocation. Munn argues that such administrators were generally not well informed or particularly supportive of their libraries. The article was based on Munn's personal observations rather than research, but it raised many provocative questions about how libraries at the time were politically positioned.

Twenty years later, Larry Hardesty took up these questions in a formal study by conducting structured interviews with thirty-nine chief academic officers from American liberal arts colleges ("college deans"). ${ }^{6}$ In contrast to Munn, Hardesty found that these administrators were relatively well informed and supportive of the work of their libraries. Those he interviewed did not perceive the library to be a "bottomless pit" in the pejorative sense. Instead, these deans regarded the libraries to be playing a central role in undergraduate education and an "important utilitarian and symbolic role in the life of the college." ${ }^{\prime 7}$ While the results of this study present a more positive picture than Munn, Hardesty's research supports some of Munn's observations. In particular, Hardesty found that administrators had only a limited understanding of their libraries: "Sometimes this strong support did not result from any considerable depth of understanding of the library and librarians. Some deans simply articulated a longheld article of faith that the library is a 'good thing'." ${ }^{8}$ Administrators often "base[d] their judgments of the library on casual observations and secondhand information."

One of the more substantial studies on the views of senior administrators is Deborah Grimes' 1998 study, Academic Library Centrality. ${ }^{10}$ Grimes explores administrators' perceptions of the library through the concept of "academic centrality": in other words, the extent to which administrators view their libraries as being core to their institutions ("the library as the heart of the university"). Grimes interviewed fourteen chief executive officers and chief academic officers drawn from seven American universities. Interview questions focused on the symbolic role of the library, relationship of the library to institutional goals and mission, resources allocation, and indicators of centrality. Grimes concluded that the concept of the library as the "heart of the university" no longer accurately describes the relationship between the academic library and its host institution.

The Grimes study was later replicated by Lynch et al. with the same framework and core interview questions. ${ }^{11}$ Interviews were conducted in 2004 with presidents, chancellors, provosts, and chief academic officers from six American universities. Lynch also found that the metaphor of the library as "heart of the university" was no longer cogent. While Grimes proposed a new metaphor for the relationship of the library to the community ("the crossroads community"), Lynch found that "the practical [role] of the library outweighs its symbolic role," and that "the library needs to employ strategies that connect what it does to the values and mission of the university." 12 The academic administrators in this study believed that the library could make its most important contribution to institutional mission by continuing to serve as a "central 
information source" of scholarly materials and to provide a "physical building [that] is important as a gathering and study space for students." 13

Later, in 2006, Estabrook conducted interviews with twenty-five American chief academic officers and provosts on behalf of the Association for College and Research Libraries (ACRL) ${ }^{14}$ As she describes it, "[t]his study was driven initially by a sense that CAOs are concerned about the costs of libraries and that librarians need to understand how to improve the way they make their case." ${ }^{15}$ Estabrook explored what kinds of factors inform the administrators' decision making about budget allocation to the libraries. Estabrook's findings are consistent with Hardesty's findings - that most of the administrators interviewed were well informed about their libraries and had positive opinions of the role of their libraries and librarians. She concludes that administrators want their libraries to be well used, dynamic, central, and integrated to the functions of the institution. Also, Estabrook found that, while administrators want to ensure that their libraries are efficient, "CAOs are not as concerned about money as they are about the library's overall role in their institutions." 16

The most recent study of senior administrators' perceptions of academic libraries was conducted by Barbara Fister in $2010 .{ }^{17}$ Her study consisted of an online survey of 134 administrators at American institutions regarding their views of their libraries. Participants were asked to indicate their agreement with statements regarding the library's roles at their institution. The respondents in this study generally tended to see their academic library's role as vital to the success of their university; while these administrators agreed that libraries need to continue to be transformed, most felt their libraries have a bright future.

While these studies all concern administrators' perceptions of their academic libraries, they differ in focus. Three themes are discernible in these studies: 1) administrators' knowledge or awareness of their libraries (Munn, Hardesty, and Fister); 2) how administrators perceive libraries in terms of resource allocation (Hardesty, Grimes, Lynch, and Estabrook); and 3) the extent to which libraries are considered academically central to the institution (Grimes and Lynch).

The results of the current study touch on some of these themes; however, this study is primarily focused on how provosts perceive the contribution of their libraries to institutional mission and priorities and how they see the relationship of the library to the institution developing in the near future. The research that bears the most relevance to the current study are Grimes' and Lynch's studies on the "academic centrality" of the library. Both provide some insight into the relationship of the libraries to the central academic mission, although ultimately these studies are more focused on the extent to which libraries are perceived as "core" or "central" rather than the specific ways in which the alignment to institutional goals are shifting. The current study also seeks to explore how provosts see the relationship of libraries to their institutions going into the future.

The focus of this literature review has been library and information science literature; however, it should also be noted that studies of senior university administrators exist outside this discipline. One of the most prominent surveys of chief academic officers is conducted annually by Inside Higher Ed. The purpose of this study is to "understand how these leaders perceive and address the challenges facing higher education institutions in the U.S." ${ }^{18}$ While the results of this report may provide some useful context, the survey contains only a single question pertaining to the effectiveness of libraries. The survey is otherwise focused at a higher institutional level.

\section{Research Design}

Provosts were selected from institutions that satisfied at least one of two criteria: either the institutions were members of the U15, or they were institutions whose libraries 
were members of the Association for Research Libraries (ARL). The U15 is a Canadian association whose members are considered the fifteen most research-intensive universities in the country..$^{19}$ ARL membership is based on a number of factors including the "breadth and quality of...collections and services," and "the research nature of the library and the parent institution's aspirations and achievements as a research institution." ${ }^{20} \mathrm{U} 15$ and ARL membership in Canada nearly coincide; however, there are two institutions that are members of one but not the other. Accepting either criterion increased the sample size slightly from fifteen to seventeen. The sole exception to the criteria was York University, which met the criteria but was excluded from the sample for methodological reasons; in this case, it would have been impossible to separate the author's role as researcher from the author's role as a librarian and administrator at York University. The resulting sample consisted of sixteen provosts at Canadian institutions.

The library director at each institution was first approached to obtain support and assistance in connecting with the provost. Provosts were not approached directly without obtaining prior support of the library director. This approach helped provide credibility with the provost and was also intended to improve the response rate. It was also a courtesy to let the library directors know that their provosts would be approached to discuss matters relating to their libraries.

The interviews consisted of seven questions, plus follow-up prompts (see appendix). The questions were divided into four sections. Section 1 contained two questions on how the provosts perceive the libraries' relationship to the institutional mission and priorities. The first of these asked the provost to reflect on the institution's overall mission and goals. This provided context for the second question in this section, which asked the provosts how they see their libraries in terms of their contributions to institutional missions and goals.

Section 2 explored how the provosts see the future of academic libraries. The first question in this section asked the provosts to imagine a successful and vibrant academic library at their university in 5-10 years. The second question probed more deeply into how the provosts envision the future of the three traditional facets of the library, namely library collections, expertise, and library as place (the physical facilities). Specifically, this question asked them to discuss to what extent they see the work of libraries being defined by these categories in the future, and which of these areas they think will become more or less important? This question was inspired by an article by Sennyey, Ross, and Mills, which argued that, while traditionally library collections, expertise, and the library as place have been inseparably bound by print culture, these facets of the library are beginning to diverge in the digital age. ${ }^{21}$ This question explored whether or not these provosts see these facets diverging, and, if so, which of these aspects they feel are most important going forward.

Section 3 focused on assessment-how do the provosts determine if the library is successful at their university and what do they see as being measures of success? Finally, section 4 consisted of wrap-up questions.

A draft of the interview questions was made available for feedback to the library directors of the institutions whose provosts agreed to participate. Some minor changes to the questions were made on the basis of these suggestions. Questions were not pretested with provosts because of the limited number of Canadian provosts and the challenges in getting access to provosts. However, the researcher did discuss the questions with the provost of his home institution to further refine and clarify interview questions.

The interviews were designed to be semistructured. This research was exploratory and based upon grounded research methodology, as described by qualitative methodologist Steinar Kvale.22 This approach allowed for some degree of flexibility and openness in the interview to draw out the participants. The purpose and nature of 
the interview was explained to the interviewees in advance, and the questions were provided to the provosts two business days prior to the interview.

All interviews were conducted by telephone. Recordings of the interviews were transcribed, and they were then coded and analyzed by the researcher using Dedoose, a web-based qualitative data analysis software product.

\section{Results}

Nine of the sixteen provosts who were approached agreed to participate in an interview resulting in a response rate of 56 percent. The provosts came from institutions across Canada. A detailed regional breakdown cannot be provided in this article due to the small sample size, which would risk identifying the participating provosts. The breakdown roughly reflected the geographical distribution of the U15 and Canadian ARL member institutions. The one exception is Quebec, which is somewhat underrepresented in the study. The sample group included three Quebec institutions, but only one agreed to participate. The window for the interviews happened to coincide with a period of turmoil in the Quebec postsecondary education sector related to the announcement of tuition increases. Provosts from the province would have been preoccupied with the budget implications of this announcement. The institutions represented in the interviews were mostly of medium size, with the average number of students being just under 26,000 FTE. ${ }^{23}$

Five of the provosts interviewed were male and four were female. On average, the respondents had been in their provostial positions for 3.4 years at the time of the interviews (the shortest period being six months, and the longest being nine years). Eight of the respondents had the title "Provost and Vice-President"; one title was "Vice-rectorat"; and one respondent was acting in the position on an interim basis. The interviews took place in the winter of 2013 between February 1 and April 2. Interviews lasted, on average, 46 minutes including introductory comments (the briefest was 39 minutes and the longest 52 minutes).

Below follows a summary of results organized into the three main sections of the interview: 1) Contribution to Institutional Mission and Priorities; 2) Envisioning the Future of Academic Libraries; and 3) Assessing the Success and Impact of Libraries.

\section{Contribution to Institutional Mission and Priorities}

The most commonly mentioned institutional priorities were: research; teaching and student learning; student experience; community engagement; internationalization; and strategic program management. Indigenous achievement and commitment to bilingualism were also each mentioned once. Of these priorities, research and a focus on teaching and student learning were the most dominant themes. Although the concern for students, especially undergraduates, was universally discussed, this theme was variously expressed as "student learning," "teaching and learning," "undergraduate education," "student success," and "student experience." While these phrases have slightly different emphases, these concepts have been grouped together under teaching and student learning since these terms were often used interchangeably. The provosts interviewed shared an overarching concern for the student academic experience even when using a term such as "student experience."

Five of the nine respondents characterized their institutions as being equally committed to research and teaching/student learning. Many provosts argued that the research and student learning missions are not in tension but are complementary. This reluctance to prioritize either research or teaching and student learning is consistent with Grimes' findings but inconsistent with Lynch's later study in which provosts tended to identify research as the primary institutional priority. 
Although many provosts described their institutions as balanced in this way, it does not follow that this necessarily represents a status quo. A provost described the balance as the result of a recent corrective rebalancing: "[U]niversities will say generally they talk about...teaching, research and service. Quite frequently the focus is on research, and this institution, I think, was no different than that, but [with the new strategic plan] there was teaching emphasized in a way, let me just say, that it hadn't been before."

In many ways, the attitude conveyed in this quote typifies the perspectives of many provosts in this sample in that often they expressed a resurgent awareness of the strategic importance of the student learning experience in these already research-intensive institutions. There was the sense that what previously may have been lip service is now considered a central concern. However, this was not unanimous. One provost discussed a greater emphasis on student experience without reference to research as an institutional priority. A few provosts also spoke of rebalancing in the other direction, namely, traditionally strong undergraduate institutions whose priority now is an intensification of research.

The second question in this initial section of the interview concerned how the provosts perceive their academic libraries positioned in terms of their institutional mission and priorities; to what extent and in which areas do they perceive their libraries contributing to their institutions' overarching mission and strategic goals?

All provosts felt that their libraries play significant roles in furthering their institution's goals. Two provosts in particular characterized the relationship of their libraries in strong terms, describing their libraries as "at the center of what universities do," "mission-critical," and as "one of the nerve centers" of the campus. The provosts were also in general agreement that their libraries align in significant ways to both the research mission and student learning. All nine of the respondents highlighted the relationship of the libraries to the research mission; seven discussed the role of their libraries in student learning experience; two provosts mentioned the connections between their libraries and the support of teaching; and one provost discussed the contribution of the library to the goal of furthering indigenous achievement.

Many of the provosts began their answer by highlighting how their libraries support the research mission by providing access to materials. One provost describes the library as a "knowledge base-so we have repositories of information and access to information. So as a research university we expect all of our researchers and all of our students to be looking at the latest literature and basing their bright ideas on research that's been done."

Another provost discusses the library's relationship to the research mission in the broader context of the knowledge life cycle, in which the libraries play the dual role of preserving and disseminating research:

[L]ibraries sit, really, at the center of what universities do.... [P] eople used to say that universities created knowledge, disseminated knowledge and preserved knowledge. And of course, the creation of new knowledge involves a recognition of old knowledge and the synthesis of new ideas of that, and the library is where those old ideas have been preserved.... So the library really is at the center of that mandate around knowledge generation, knowledge preservation and knowledge dissemination.

All provosts stressed the importance of collections to the research mission, but they also acknowledged the role of collections in supporting teaching.

The theme of access to collections formed the bulk of the provosts' reflections on the library's contribution to the research mission; however, a few provosts reflected 
further on other ways libraries are or could be contributing to research at their institutions. One provost refers to the role of "embedded librarians in research teams" as one way in which the library supports research. Another, however, reacted strongly against this concept:

There's a notion amongst librarians, not just at this institution but other ones that I've talked to recently, where librarians are saying, "You know, we'd be really helpful in research grants; we'll do the background research for you," and I'm not sure where that came from because you have to do the research yourself. It's an odd service to be going into providing, and so I'm kind of watching to see how this works out... I'm not sure that that's a new service that's going to have legs, but then I'm often wrong.

In contrast, another provost had been influenced by a report submitted by his library director with a vision for e-research at the institution. This provost had a concept of the library's potential role in research that could extend beyond access and storage of research to roles in the facilitation and creation of knowledge as well. This same provost also suggested that he believed that the library at his institution would be the logical home for a university press.

As mentioned, the provosts also generally agreed that their libraries contribute substantially to student learning and experience. The most commonly mentioned contribution in this area was the library as place. Provosts highlighted two related aspects of the role of the physical library: 1) the library as a student learning space; and 2) the library as learning commons, understood as a model for enriched learning services and supports.

First, in terms of library as student learning space, the provosts described their library facilities as being packed with students. Five of the provosts talked specifically about the importance of the physical library to student learning on campus. One of the strongest statements is as follows:

You know, on our campus the library is in the heart of the campus. It is a critical, critical, critical gathering place, if you will, for students. It's a social space [...] so there's all kinds of opportunities for students to meet, to talk in groups about the kinds of studying they are doing. It's also a chance where people can be quiet if they want to study. It's one of the few buildings that is open almost constantly, and it's probably one of the busiest buildings on campus. So I think a library has a place, if you will, in terms of the gathering place, being the heart of the campus, one of the nerve centers where people go to meet, study, talk and think very carefully about their education.

The provosts described dynamic environments conducive to collaboration, creative thought, dialogue, group work, technology use, in addition to solitary contemplative thought. They recognize how quickly libraries have evolved from the traditionally undifferentiated quiet study halls of the past and are enthusiastic about these changes. Related to this is the concept of the library as a focal point on campus for cultural and civic engagement.

[The library] really has become this focal point of the campus. It's smack in the middle of the campus. It's being used for campus events. So, everything from art exhibitions to... we do that. We were one of the first to do the human library borrow-a-book.... The whole author recognition event, which I got to host this year, which was my 
favorite event where we recognized all the folks on campus who had written books, and we do an event in the library. The sense of place, I think, has really blossomed.

This kind of "town square" engages the campus community by offering programming and events that are not necessarily directly related to students' coursework or faculty research.

Second, related to the library as a physical facility for students is the concept of the learning commons. Four of the nine provosts stressed the significant contribution of the learning commons to student learning and success. The provosts described the learning commons as a model that integrates a variety of academic services, such as writing, learning skills, and math supports. One respondent talks about this development on her campus: "I think, frankly, that the library's role is morphing into being kind of a one-stop-shop, the service center for learning and research, so a much more expanded version in terms of the learning commons." One provost emphasizes how essential the learning commons is to the institution's student success strategy:

In the whole core mission, which is teaching,...[the libraries are] really strong partners and have been for years since they created one of the first learning commons in the country dedicated to the support of teaching and learning.

So, definitely, in terms of partnering on student success...I would say that the library is a key partner and an important partner in those aspirations.

Two provosts talked explicitly about how they see their library's role in the student learning experience growing and expanding through initiatives such as the learning commons. For instance:

I think traditionally we thought about libraries as contributing very much through collections to the academic programs of the university, both the educational programs and the research programs of the university, and I think that is a continuing way in which libraries make contributions, but I also think that increasingly we are looking at libraries and the role that they can play in the provision of an outstanding student experience, and that's not just through collections, right, but that's also through the services that they provide and the spaces that are provided to students, you know, through learning commons and the like.

As some of these provosts see it, these new roles have substantially expanded the library's contribution to the institution's mission. They perceive the libraries as playing a more central role in student learning by providing quality facilities and expanded models of academic support.

Finally, one other minor theme deserves mention. Some provosts suggested ways in which their academic libraries might contribute to the goal of supporting teaching activities. In places, the provosts referred to the role of librarians teaching students individually or in classroom settings; but, at a few points, the provosts went further and began to suggest how the library might support instructors themselves in the development of teaching.

I see an increasing integration between our library and our teaching and learning center. I'm not quite sure exactly how that's going to play out, but I think there's a very significant overlap in the roles...the teaching and learning center actually supports the learning technologies on campus, but the library is really engaged in those things, so I think there's a really important synergy to be had there. 
And, in the following quote, the provost explores the library's relationship with the teaching and learning center. It seems that the success of the learning commons model has raised the question of how a center for teaching support might also fit in:

We have a learning commons in the library.... Why wouldn't you co-locate the Center for Teaching and Learning with a learning commons? Neither intrinsically has to do with the traditional role of what the library does, the library learning commons more so than the Center for Teaching and Learning; but to my mind the co-locating things like that is... and ideally within the library, really speaks to position in the library at the heart of the university and the support that it provides for all the activities that go on at the university.

\section{Envisioning the Future of Academic Libraries}

The second section of the interview concerned the provosts' perspectives on the future of academic libraries. This section consisted of two questions: the first asked the provost to imagine and describe "a successful and vibrant academic library at this university in 5-10 years." The second asked the provosts to consider collections, expertise or services, and library as place and to give their perspective on how they see these facets of library work evolving over the next $5-10$ years.

When asked to envision a library in ten years, the provosts touched on themes such as library as place, digital collections, expertise, and emerging roles in the university. The respondents focused on current trends in libraries and higher education, which they projected into the future.

\section{Collections}

Here, as throughout the interviews, the provosts discussed the continuing migration from print to digital. They recognized that this process of migration is advanced, though it still has some way to go. Some provosts also understand that digital formats have been adopted more readily in some disciplines than others for a variety of reasons. Nonetheless, the respondents were aware that circulation rates of print materials are in decline, and digital materials have become or are still becoming the preferred format. The provosts agreed that this process will continue.

What do the provosts think the repercussions of this shift from print to digital will be? For one: while, in the past, print collections were built locally for local needs, many of the respondents see that academic collections are and will continue to become increasingly networked and convergent. The provosts expressed an appreciation for the consortial and collaborative approach to collection building in the digital age. In fact, one provost suggested that phenomenon is part of a broader trend in higher education: "[U]niversities, I think, will become more tightly networked with a small subset of like universities around the world. I think that the future of universities is more networks...." A few provosts commented that they see libraries as "ahead of the curve" compared to others on campus in the ways they have collaborated at the provincial and national levels to build infrastructure.

However, just as there is a dual movement in higher education of cooperation and differentiation among institutions, so too with collections. While there is undeniably a process of convergence of networked collections, there is also greater value placed on those collections that are unique to each institution, especially special collections and archives. Several provosts commented on the importance of this unique material. For example: "I think that the future of universities is more networks - that in some ways we're evolving back to our medieval roots; and, as such, universities will bring value 
to that network by their special collections and the things that they have that allow scholarship in that area, and that won't be duplicated in other libraries."

When discussing digital collections, provosts would on occasion refer to these collections as being somehow distinct from the library. For example:

[S]ix years ago I had three PhD students at [another university], and I continued to supervise those three students [remotely], so I didn't use the library for my scholarship. You know, I just used the digital technology - the journals, the databases, etc. - from a distance, and so libraries,...the physical space of library versus the virtual space of libraries is just a completely different paradigm from where we were before.

There is a sense in which digital collections, while clearly the work of the libraries, is not identified in some respect as constituting the library. The library continues to be substantially identified with the physical building. This brings us to a discussion of library as place.

\section{Library as Place}

Although collections will continue to migrate out of the stacks and into the cloud, the future of the physical library appears very bright according to these provosts. All nine provosts spoke very positively about the future of library as place. In fact, seven of the respondents began their responses to the first question that asked them to envision a "successful and vibrant academic library" in ten years by first highlighting the importance of library as place. All felt that, while the physical library has and will continue to be transformed over the next decade, it remains of vital importance on campus for students. Some provosts used metaphors to describe the place of the library on campus, such as "hub," "focal point," "heart of the campus," "gathering place," and "nerve center."

Only one provost expressed any hint of doubt about the long-term viability of the library as a physical facility; in this case, despite a renovation at his institution, the provost wondered: "[T] he physical facility would still be there if it's only in fact ten years. In twenty, thirty years I have no idea." One other provost felt that, in the future, libraries would likely occupy a smaller footprint. Otherwise, the comments regarding the future of the physical library were overwhelmingly positive.

One provost drew a parallel between the debate over library as place in the digital age with debates over the role of the campus in the age of online learning. He argued that, despite some scenarios, he continues to have great confidence in the need for physical environments:

We worry about place, generally, I think, at institutions. And, you know, there have been some people that would go so far as to say universities generally as a place will no longer exist.... And I actually don't subscribe to that. I think universities play a very important role in society.... I still would subscribe to the tenet that face-to-face learning, at least in part, is really critical; and so I guess if I was pushed I would say if we do have libraries that exist in some varied form of what we have now, that a library at the center would still be a critical piece of that, whether it was from a learning commons perspective, from a social gathering point, from a place where people could come and congregate to talk about issues, that a library would still have a very important place. Now, would it be necessarily as physical as we have today?... I still think a library, whether it's a digital heart place or a physical heart place, would still be one of those key connectors for any university. 
And according to the provosts, what exactly will the physical library be like? First, they agree that the footprint of print material will be substantially reduced to accommodate the growing need for student learning space. Instead of consisting of shelves of volumes, the library will be:

Full of people! So that's where I see the shift. It's more people-oriented in there rather than shelves and shelves and shelves of books, so we've already, as I said, begun that and we increasingly expand that effort every year.... [I]ncreasingly I would see in five to ten years that just continue, and so you would find fewer and fewer physical objects, more and more digitization of learning objects, but more physical presence of people in the library.

One provost called the library a "point of integration" and went on to say, "if we could get some of our student services and academic support units a bit more out of the 9-to-5 mode, I could see other student services being able to be provided from the libraries." The physical library is then becoming a kind of platform for learning on campus:

So the fact that the students are coming into the library because that's where we have study space, provides an opportunity for librarians to say, 'Well, while you're here, here's stuff that we can do to help you, and here's how our expertise is relevant to your studies whether you're an undergraduate or a graduate student.' So I think that's where librarians need to grasp hold of this, as a challenge, but an opportunity that presents itself as a consequence of different uses of the space.

For many provosts, the transformation of the library from a repository to a learning commons has positioned the physical library to play a key role in student learning and success. In sum, the provosts interviewed felt almost uniformly positive about the future of the library as place.

\section{Services and Expertise}

The respondents continue to see a substantial role for library services and expertise; but, as with many aspects of libraries, they foresee significant changes in this area in the coming decade. The provosts focused much of their discussion in this area on their perceptions of the changing roles of librarians. Some also spoke about the need for librarians to be complemented with a variety of other types of professionals.

There was a general theme in the comments that librarians need to become more active and embedded partners in the research, teaching, and learning activities of the university and move away from the more limited traditional roles of providing support via services such as reference: “...it's really the change or the shift and the real embedding of the expertise and services that the librarians bring as partners to our core missions, which is teaching and learning and research." This same provost felt that this shift is already happening on her campus:

I really did witness...where there still was resistance on the academic side, to treating those players [that is, librarians] as supporters, not as fundamental contributors and equal contributors to the exercise, and I've seen that shift. Yeah, there's been a shift-a recognition that librarians offer expertise and skills and services that we need that faculty don't provide, can't provide.

The provosts provided some examples of how librarians might take up new, more active roles. In terms of research, several provosts commented that they could see 
librarians being more frequently embedded in research teams. One provost talked about her discussions with the library director:

...our discussions [have] been more around...the way in which librarians interface with the faculties and the researchers themselves, as really being part of the... research team.... [A]nd I think also that libraries seem to be increasingly called on to provide expertise around data management.... So with digitization and information technology, they've got skills that I think researchers are increasingly interested in tapping into, so I see librarians as becoming more collaborators in the research enterprise.

Another provost characterized libraries and librarians as having "more of a role in content creation as opposed to content delivery." Most provosts in this sample envisioned librarians taking on more active and embedded roles in research, though was this was not unanimous.

On the side of teaching and learning, several of the provosts commented on how they see librarians continuing their role teaching students. For example, "I would not invest anymore, of course, in traditional bookshelves, but more in people who can train our students, and have a teaching role of our students on our use of the information in the most efficient way." Though some provosts talked about this, none used the term "information literacy."

Five of the nine provosts talked about how they foresee the libraries taking on a greater collaborative role with faculty and teaching support units around pedagogical developments. In particular, many provosts feel a sense of urgency in developing their institution's e-learning capacity, whether that be in the form of blended learning, MOOCs, or other approaches, and they believe that the libraries could play a key role in helping develop this capacity. For example:

The library's role in open educational resources and what that might look like, and particularly playing a role in copyright around open educational resources, around leading discussions on academic freedom. For example, how... we change and go more digital, more online to MOOCs and that kind of thing, who owns the material and how do we protect the rights of individual faculty members who have spent considerable time developing the materials? I think there are many things that we can see, but probably open educational resources, copyright.... [L]ibraries would play a lead role in the development of new policies and procedures, and certainly in the development of materials and in creating materials.

In this case above, the library's role would be specifically in the development of e-learning policy and models. The role of the library in providing leadership on copyright came up several times in the interviews. In other cases, the role would be in the support of "curriculum innovation and curriculum reform."

One other area mentioned by one provost in which the library is perceived as possessing considerable expertise, is the area of evidence-based decision making and assessment: "[T]hey've been one of the leaders in terms of making sure... which is kind of interesting because I think the academic departments are sort of just coming into that now, right?" This same provost argued that the library is also a leader on campus in terms of the development of "learning outcomes assessment."

Aside from librarian expertise, two of the provosts also suggested that the library of the future would need to have a greater mix of different types of professionals in addition to librarians. 


\section{The Question of Disaggregation}

The second question in the section on the future of academic libraries asked the provosts to consider the three traditional areas of libraries (collections, expertise, and space) and reflect on how they see those facets evolving over the next 5-10 years. Specifically, this question asked them to discuss whether or not and to what extent they see the work of the libraries in the future being defined by these categories, and which of these areas they believe will become more/less important?

Most of the provosts interviewed believe that all three areas of library work will continue to be important. Many also stated that they believe the facets will continue to be roughly equally important. However, all agreed that, to maintain relevance, these three areas would each need to be transformed in their own way. For instance, many outlined how they believe collections need to continue migrating online; space needs to become increasingly learner-focused; and expertise needs to adapt to embrace new skills for the digital age and seek integration across campus.

The only area in which there was any uncertainty was in the area of expertise and services. Two of the provosts equivocated on whether library expertise would continue to have ongoing relevance. Initially, both provosts stated that expertise would decrease in importance in the near future. For example:

I would say...the expertise and services-yes, there will be services, but they might be different kinds of services than we rely on now. And, interestingly, I think expertise might not be so important because, you know, people can get on and read about things and not bother people right now, so I think we're almost seeing a shift in the expert model there, even though you and I could agree that the expertise is absolutely critical in setting some pieces up.

Both argued that, on some level, research has become much easier, and therefore assistance is less necessary. Decreasing reference statistics were cited in this context. However, both also clarified that this trend would ideally be offset by the development of new roles for librarians:

[I]f the services stayed pretty much as they are they would decrease in importance, but I don't see them staying that way. So, I think along the lines of what I said to the answer to the previous question about the way in which librarians would interface with faculty and actually provide service in a more collaborative role. I think that's something that will change over time and will be increasingly important.

This may suggest that, while the trajectories of collections and library as place are fairly clear in the minds of these provosts, the evolution of services and expertise is somewhat less clear. The provosts seemed confident in the future roles of collections and space, as their transformations are already underway; but they seemed to suggest that library expertise would only secure its future if it is transformed.

As a follow-up to this question, provosts were asked whether they see these three facets (collections, expertise, and place) continuing to constitute an integral whole. Responses to this question were varied. One provost responded:

[T] o my mind, the various things you've described are joint products, you know, so a bit like a sheep that produces mutton and wool, and so it's a bit like, you know asking someone if the wool is going to become more important or is the mutton? Well, the sheep produces them both and you can't divorce one from the other, and I think there's a certain truth to that from the point of view of the library. 
Three other provosts expressed confidence that libraries would continue to be defined by these three areas, but they suggested that libraries would need to forge new connections among the facets of collections, expertise, and place: "I do think regardless of how you put things together that there would still be a central organizing function of some form or fashion, but it might be a digital organizing fashion, not a bricks-and-mortar fashion - like, a virtual fashion, right?" And another provost stated: "I still kind of see them all connected, but I see the way that they connect and the way they would actually be delivered, and be enacted as not being the same as what they are now."

Two provosts, however, questioned the ongoing relationship between these aspects of the library. One focused his comments on the library as place and speculated how a facility might be built if the library at a university were being built from the ground up.

[I]f you were building a library from scratch, I don't think you would build what we have now or anything like that. What you would build would be some spaces that would probably be, first of all, structurally much more simple and cheaper spaces where students could gather and work together and have access to computers and wireless and stuff, just be able to gather and do the things that they want to do.... I think physically the buildings would be much smaller, and they would be there so that you would have the space for the librarians to work and to meet with students and staff that wanted to use their resources, and specialized places dedicated to those kinds of resources that are not necessarily digital-special collections and things of that nature. So I think you would not build a physical infrastructure that looks anything like a modern university library.

It is not clear in the preceding quote whether such a building would be considered a library, but this provost goes on to say that, in existing institutions, new functions and kinds of spaces are being incorporated into existing library facilities mostly because of historical contingencies.

So I think that the libraries are being used in part because it's a kind of a confluence of things that have happened almost independent of each other. I mean, the digitization of the collections has led to... a dramatic decrease in the amount of library space which is taken up by storage of books. At the same time that students are beginning to see the university as a place to hang out and work together, and they need a space to do that, and it just so happens that there's this space available in the library because the books left, so that does lead to, in some sense, a separation of those issues.

Another provost explores these ideas even further:

I think that the value is actually in the collections and services, but I guess I would argue that those two things probably are no longer tightly coupled with the notion of an academic library as the resource of the university.... We have a certain amount of infrastructure. You know, we've got a head librarian, we've got a bunch of other librarians, we've got a place, right? So we've got a structure that does these three kinds of services, right? So if there were actually no books, maybe we should just have resource people in the different faculties that help people do stuff and not have a library at all. 
I'm not actually suggesting that. But, you know, if you look in the crystal ball, there is a movement away from having things...stored the way that they were when they were paper.

To be clear, neither provost suggested that these facets should be disaggregated at their institutions. However, it appears that these provosts believe the question of disaggregation has merit, and that eventually there might be legitimate questions raised about how to structure the facets of library work at an institution.

\section{Indicators of Success}

The fourth section of the interview inquired into how the provosts determine whether their library is successful at their university. The responses to this question were varied. Interviewees responded to this question by discussing formal measures and informal influences on their perceptions of library success.

The most common response was that provosts consider usage data to be a reliable indicator of success and that such data provide justification for library investment. Provosts referred to collections, services and physical facilities usage data as examples.

Four provosts talked about the importance of impact or outcome measures (such as learning outcomes or data showing impact on research productivity); however, all four also agreed that impact is extremely difficult to measure. No provost cited examples of useful impact data. One provost, however, reflected on some of the reasons impacts of libraries are so difficult to measure. When it comes to collections, he observed:

I would say one measure of impact is, in fact, that the library's resources are seamlessly integrated with all of the learning resources on campus. I think that would be a measure of success in some sense.... [S]o then trying to parcel out of that what is the actual role of the library, and that is going to be, I think, very challenging, particularly because, you know, we don't even know when the students are using the library. In fact, it's not even clear in some instances when you're using the library that that's actually what you're doing.

While many provosts agreed with the importance of impact and outcome data, none had ideas on how to obtain it. For many, clear and meaningful impact data are an as yet unattainable ideal.

Some respondents discussed satisfaction data. For instance, two provosts referred to LibQual+ data. In the absence of hard data, others mentioned informal feedback from the university community - from faculty, staff, and students. One provost talked about feedback received from students and faculty deans in the process of budget planning. Several provosts also talked about how their impressions of the success of a library were influenced by the external reputation of the library:

For example, when people come to conferences from around the world where we host events and people talk about the impact of the library, how they would rate it. There's an informal international community that has been in [name of institution] at our library that provides opportunities for input that we wouldn't have otherwise, and that provides, can I say, an informal ranking of how they would review our library relative to other libraries. So that's an important one.

Two provosts also talked about the national and international reputations of their library directors as an indicator of the success of the library leadership. 
Finally, two provosts talked about how for them an engagement with the institutional strategic plan was a key influence in their assessment of the library's success. One provost remarked: "When I think about it, I go back to our strategic plan and I ask what impact is the library having on those areas that deal with our strategic plan, and in many cases those stories are as important to me as the metrics."

In summary, it did not appear that these provosts had consistent and systematic measures for assessing the success of their libraries. In the absence of reliable impact measures, usage data appears to make the most significant impression on provosts. After that, informal feedback from campus stakeholders as well as from peers at other institutions make the most significant impression on the provosts' perceptions.

\section{Discussion}

The purpose of this research was to explore how provosts at Canadian researchintensive universities perceive the relationship of their libraries to the mission and goals of their institution; the future of academic libraries; and indicators of success.

In general, the provosts interviewed in this study perceive their libraries to be playing a vital role in areas they see as central to their university's mission: research and student learning. Similar to Grimes' findings, the provosts in this study were reluctant to assign priority to research over teaching and learning or vice versa. If anything, these provosts perceive a new rebalancing of these two key missions, and the libraries are seen to provide significant value on both sides of this equation. The provosts see the main contribution of the library to research as being grounded primarily in providing access to the scholarly literature. Some were aware of other more active roles the libraries might play in support of the knowledge life cycle (for instance, at the point of the creation, curation, and dissemination of knowledge); however, these other potential roles were not clearly articulated by the provosts.

Ithaka S+R's 2012 US Faculty Survey shows a continued erosion of faculty's perception of the importance of the academic library's roles related to access, such as "gateway," "buyer," and "archive." The most recent iterations of the Ithaka Faculty Survey are also now beginning to track changes in how faculty perceive the library's role as "research support," defined as how "[t]he library provides active support that helps to increase the productivity of my research and scholarship." ${ }^{24}$ It remains to be seen how more active and embedded roles of research support will fare over time; however, there are other models of how libraries can be more deeply integrated into the knowledge life cycle beyond information access. In 2002, Wendy Pradt Lougee wrote that

...we see the library becoming more deeply engaged in the fundamental mission of the academic institution - i.e., the creation and dissemination of knowledge-in ways that represent the library's contributions more broadly and that intertwine the library with the other stakeholders in these activities. The library becomes a collaborator within the academy, yet retains its distinct identity. ${ }^{25}$

Despite the perceived erosion of the role of the library in facilitating access to material in the Ithaka study among faculty, access to information continues to be the library's most prominent role in support of the research mission, according to the provosts in this study. There appear to be some signs of openness to other types of more active and integrated roles; however, these do not yet appear to be prominent in the minds of these provosts.

Meanwhile, the provosts see a significant contribution of their libraries to student learning, particularly when it comes to library as place. Almost all provosts expressed an appreciation for the role of the physical library in student learning, especially for 
undergraduate students. Aside from the value of space for students to gather and work, many provosts spoke about the learning commons model, and the ways in which the library as place has become a platform for the co-location and collaboration of learning supports and other services. This model was seen as a significant trajectory for the future of academic libraries on campus. Interestingly, some provosts also extended the concept of the library as platform to encompass collaborations with teaching support and pedagogical development. These provosts appear to appreciate the ways in which libraries may be evolving into learning "ecosystems" capable of incorporating a variety of services and types of professional expertise beyond the confines of traditional librarianship. ${ }^{26}$

By contrast, the teaching roles of librarians were infrequently mentioned by the provosts; and, of the few that did acknowledge the role of librarians in teaching, none used the term "information literacy" to describe this work. In a 2013 survey, Ithaka $\mathrm{S}+\mathrm{R}$ asked American library directors what they perceived to be the most important functions of the library from the perspective of their immediate supervisor (that is, provost or chief academic officer). Interestingly, the library directors believed that their supervisors would place greatest importance on the role of the library in helping undergraduates "develop research, critical analysis, and information literacy skills." ${ }^{27}$ Library directors believe that roles related to access of information ("buyer," "archive," and "gateway") would rank as less important for their immediate supervisors. The provosts in the current study perceive the opposite: namely, they place greater emphasis on the role of the library in providing access to information. The role of librarians teaching critical thinking, research skills, or information literacy is less prominent in their minds.

The theme of collaboration was pervasive in other ways throughout the interviews, especially in the provosts' discussions of the future of academic libraries. This theme was evident in discussions of the learning commons, pedagogical developments, to a somewhat lesser extent in the research context, but it was also prominent in their discussions of collections. The provosts were keenly aware of the ways in which library collections are increasingly built collaboratively through consortia and how collections are consequently converging (with the exception of special collections whose unique materials help differentiate collections).

The two trajectories that emerged most clearly from the provosts' comments were 1) a movement of the collections out of local facilities into an interinstitutional cloud; and 2) a reinvention of library space as a vital campus platform for student learning. In regard to expertise and services, some provosts described a gradual shift toward more active and embedded roles; however, this shift was not as unambiguously expressed by the provosts. In regard to the first two trajectories, one might reasonably wonder whether the dual movements of collections and library as place could result in a divergence of these facets of library function.

The issue of the potential divergence of facets of traditional library work was discussed as part of the interview by introducing and testing some of the concepts of Sennyey, Ross, and Mills' 2009 article regarding the changing nature of academic library collections, facilities, and services. While the trajectories described by the provosts roughly follow those sketched by Sennyey et al., most provosts did not perceive any resulting tensions that would pose an existential challenge (or "definitional" in the language of Sennyey et al.) to the library as institution.

However, a minority of provosts did appear to accept that the trajectories and transformations of these library facets raised legitimate questions about how these aspects might be organized in the future and whether they might not necessarily constitute a library as currently conceived. Several other provosts stated that, while they believe 
the facets of collections, space, and services will remain vitally important, there may nonetheless be a need for a new framework capable of articulating the common denominator in the digital age.

In her report on emergent roles for research libraries, Lougee argues that

the changes under way reflect an evolutionary path in which, as distributed and collaborative models emerge, libraries are taking on far more diffuse roles within the campus community and beyond. That is, libraries are becoming more deeply engaged in the creation and dissemination of knowledge and are becoming essential collaborators with the other stakeholders in these activities. ${ }^{28}$

It appears that provosts in research universities perceive a host of new opportunities afforded for libraries in the digital age, and they see these opportunities contributing in substantial ways to institutional missions and goals. At the same time, libraries are evolving in many new directions and pushing at the boundaries of how traditional libraries have been defined. Increasingly, collaboration has become one of the hallmarks of academic librarianship, from learning commons partnerships, to consortial collection building, to embedded librarians. As libraries develop and extend collaborative roles, libraries become more "diffuse" (to use Lougee's term) but, by the same token, potentially more impactful. At this point, the provosts interviewed in this study do not, by and large, see these trajectories as a disaggregation of library function so much as an engagement with institutional goals and a diffusion of impact. Regardless, there are nonetheless minor strains in evidence that suggest that it may be worthwhile for academic libraries to better articulate an overall framework for the road ahead.

Finally, it appears that provosts struggle with identifying indicators of success related to their libraries. While they clearly appreciate the need for reliable indicators for evidence-based decision making, such indicators were seen to be hard to come by. Basic library usage data was valued, but the provosts in this study seemed just as influenced by informal stakeholder feedback and factors relating to external library reputation.

\section{Limitations and Further Research}

This study provides insight into how provosts at large Canadian research-intensive universities perceive the role of academic libraries in the context of their evolving institutions. It should be noted that, although the response rate was relatively high (56\%), the overall sample was small (provosts from 17 institutions). While the study provides useful insights into the perceptions of provosts at Canadian research-intensive institutions, it is not a broadly representative study, and it may be difficult to extrapolate to other types of postsecondary institutions, such as smaller undergraduate-focused colleges or universities. And though Canadian research-intensive institutions share much in common with those in the United States, it is also possible that some aspects of the findings are influenced by the Canadian context (such as the fact that the vast majority of Canadian universities, and all of the participating institutions in this study, are publicly funded). These considerations must be noted in attempting to extrapolate the results of this study to other contexts. Nonetheless, the study is intended to surface general trends and tensions.

The research raises a number of questions that may serve as avenues for further research. First, these findings suggest ambivalence in these provosts' perceptions of library expertise. To what extent do other administrators perceive, understand, and support the transformations under way in librarians' roles? Second, the findings of the current research suggest that provosts tend to prioritize the collection roles of the library over the library's role in teaching research and other skills. This conflicts 
with Ithaka S+R's Library Survey 2013, which indicates that library directors perceive the library's teaching roles to be of greatest importance to senior administrators. This raises the question whether library directors accurately understand provosts' perceptions of library roles. And, finally, this research suggests that there may be a need to further explore how our communities perceive the divergent roles of academic libraries in the digital age and the extent to which the various facets of our evolving work will continue to meaningfully constitute an integral whole in the minds of our stakeholders.

\section{Conclusion}

In general, the provosts in this study perceive academic libraries as making vital contributions to institutional mission, particularly in the areas of research and student learning. Likewise, the provosts see a bright future for their libraries - a future that requires continued transformation, but a strong future nonetheless. There was little evidence of views that could be construed as fundamentally questioning the continued relevance or vitality of academic libraries within research-intensive universities.

The traditional role of the library in providing access to scholarly content remains the most prominent contribution in the minds of provosts toward the research mission. Meanwhile, these provosts see the reinvigoration of the library as place in the form of the learning commons and enriched learning environments as a significant contribution to the student learning mission. In terms of expertise, the provosts in this study see services offered by libraries as contributing equally to the research and learning missions. Provosts, however, also perceive library expertise in the process of a transformation by which librarians' roles are shifting toward being more integrated and embedded throughout the institution, while at the same time new kinds of expertise (and professionals) are being incorporated into the library.

The value of this study's results are not just in these overarching themes where there is relative agreement among the provosts but also in the more subtle patterns that emerge from the interviews. Though not yet widespread, there are suggestions that some provosts may be beginning to appreciate new roles for the library in research that go beyond facilitating access and discovery and encompass more active engagement in the knowledge life cycle. That these roles are not yet top of mind for these provosts may signal the need to promote and advocate more effectively for such expanded and enriched roles. Some provosts are also beginning to identify synergies between the libraries and teaching support units on campus, which could open up new strategic horizons for libraries. Finally, there are suggestions that the rapid transformations of academic libraries may at some point warrant a renewed discussion of library mission that would be capable of encompassing the increasingly divergent roles of the library in the digital age. Such discussions would help ensure that academic libraries develop strategically and remain able to effectively communicate their institutional identity as traditional roles change. 


\section{Appendix: Interview Questions}

\section{A. Contribution to Institutional Mission \& Priorities}

1. To help put things in context, can you please talk a little about this university in terms of its mission and its strategic goals. What's important for this institution now, and how do you see the institution evolving in the next 5-10 years?

Follow-up questions (optional)

- Do you see any shifts or realignments in the mission of the university in the near future?

- Do you see any shifts in terms of the relative importance of teaching, research, and learning?

2. Where do you see the library contributing most substantially to the mission and the strategic goals of this institution? How and to what extent do you see the library helping the institution achieve its goals?

Follow-up questions (optional):

- How do you see the library's role in terms of the missions of research, teaching, and learning? Do you see the libraries as being more aligned to the research, teaching, or learning missions?

\section{B. Envisioning the Future of Academic Libraries:}

3. Imagine a successful and vibrant academic library at this university in 5-10 years. What do you imagine this library would be like?

4. Traditionally academic libraries have consisted of 3 interrelated spheres: a) collections - the resources libraries collect (such as print, digital, archival); b) expertise/services - the knowledge and know-how provided by the people from the libraries; and c) places - the library as place and as learning environment. Which of these areas do you think will become most important/least important over the next 5-10 years? And do you see these three facets remaining an integral whole?

\section{Assessing the Success and Impact of Libraries}

5. How do you determine if the library is successful at this university? What for you are the measures of success?

Follow-up questions (optional):

- What kinds of tangible impacts do you see the library having on the institution?

\section{Wrap-up}

6. Is there anything about the libraries at your institution that makes you particularly proud?

7. Do you have any other comments about the library at this institution or about the role of academic libraries in general?

\section{Notes}

1 Eleanor Rodger, “What's a Library Worth?" American Libraries 38, no. 8 (2007): 59.

2. Ibid., 60 .

3. Ray Maghroori and Charles Powers, "Vice President vs. Provost," Chronicle of Higher Education (Aug. 2, 2007), available online at http://chronicle.com/article/Vice_President_vs_Pro- 
vost/46483 [accessed 18 March 2014].

4. Paul N. Courant, "The Future of the Library in the Research University," in No Brief Candle: Reconceiving Research Libraries for the 21st Century (Washington, D.C.: Council on Library and Information Resources, 2008), 22.

5. Robert F. Munn, "The Bottomless Pit, or the Academic Library as Viewed from the Administration Building," College \& Research Libraries 29, no. 1 (1968): 51-54.

6. Larry Hardesty, "The Bottomless Pit Revisited," College \& Research Libraries 52, no. 3 (1991): 219-30.

7. Ibid., 227.

8. Lloyd W. Chapin and Larry Hardesty, "Benign Neglect of the 'Heart of the Library': Liberal Arts College Deans Look at the Library," in Academic Libraries: Their Rationale and Role in American Higher Education, Contributions in Librarianship and Information Science 84 (Westport, Conn.: Greenwood Press, 1995), 29-41.

9. Hardesty, "The Bottomless Pit Revisited," 227.

10. Deborah J. Grimes, Academic Library Centrality: User Success through Service, Access, and Tradition, ACRL Publications in Librarianship no. 50 (Chicago: Association of College and Research Libraries, 1998).

11. Beverly P. Lynch et al., "Attitudes of Presidents and Provosts on the University Library," College E Research Libraries 68, no. 3 (2007): 213-28.

12. Ibid., 226.

13. Ibid., 219, 226.

14. Leigh Estabrook, "What Chief Academic Officers Want from Their Libraries: Findings from Interviews with Provosts and Chief Academic Officers" (Association of College and Research Libraries, October 2007), available online at http://www.ala.org/acrl/sites/ala.org.acrl/files/content/ publications/whitepapers/Finalreport-ACRLCAOs.pdf [accessed 28 July 2013].

15. Ibid., 4.

16. Ibid.

17. Barbara Fister, "Critical Assets: Academic Libraries, a View from the Administration Building," Library Journal 135, no. 8 (2010): 24-27.

18. The 2014 Inside Higher Ed Survey of College and University Chief Academic Officers (Washington, D.C.: Inside Higher Ed, 2014), 5.

19. For more information and a list of member institutions, see "U15: Group of Canadian Research Universities," available online at http://u15.ca/ [accessed 28 July 2013].

20. Association of Research Libraries, "Principles of Membership in the Association of Research Libraries," available online at http://www.arl.org/storage/documents/publications/membershipprinciples-2013revision-final.pdf [accessed 7 April 2015].

21. Pongracz Sennyey, Lyman Ross, and Caroline Mills, "Exploring the Future of Academic Libraries: A Definitional Approach," Journal of Academic Librarianship 35, no. 3 (2009): 252-59.

22. Steinar Kvale, Interviews: An Introduction to Qualitative Research Interviewing (Thousand Oaks, Calif.: Sage Publications, 1996).

23. Based on figures in Canadian Association of University Teachers, "CAUT Almanac of Post-Secondary Education 2012-2013," available online at http://www.caut.ca/docs/almanac/20122013-caut-almanac-of-post-secondary-education-in-canada.pdf?sfvrsn=0 [accessed 28 July 2013].

24. Ross Housewright, Roger C. Schonfeld, and Kate Wulfson, Ithaka S+R US Faculty Survey 2012 (Apr. 8 2013), 66, available online at http://sr.ithaka.org/research-publications/us-facultysurvey-2012, [accessed 7 April 2015].

25. Wendy Pradt Lougee, Diffuse Libraries: Emergent Roles for the Research Library in the Digital Age (Washington, D.C: Council on Library and Information Resources, 2002), 4.

26. Scott Walter, "The Library as Ecosystem," Library Journal 133, no. 16 (2008): 28-30.

27. Matthew P. Long and Roger C. Schonfeld, Ithaka S+R US Library Survey 2013 (Mar. 11, 2014), available online at http://sr.ithaka.org/research-publications/ithaka-sr-us-library-survey-2013 [accessed 7 April 2015].

28. Lougee, Diffuse Libraries, 1. 